\title{
Comparative study of surface modification on bond strength of polyetherketoneketone adhesively bonded to resins for temporary restoration
}

\author{
Mun Gi Hong, Soo-Yeon Shin* \\ Department of Prosthodontics, College of Dentistry, Dankook University, Cheonan, Republic of Korea
}

\begin{abstract}
Purpose: The purpose was to compare shear bond strength (SBS) of three types of resin for temporary restoration to polyetherketoneketone (PEKK) depending on surface modification. Materials and Methods: Sixty disks made from PEKK were air-abraded with $110 \mu \mathrm{m}$ alumina particles (Cobra, Renfert $\mathrm{GmbH}$, Hilzinge, Germany) and thirty specimens were divided into two groups each: PEKK without Visio.link (Bredent, Senden, Germany)(U) and with Visio.link (P). Resins for temporary restoration (polymethylmethacrylate; PMMA, polyethylmethacrylate; PEMA, bis-acryl composite resin) in the shape of a square with one side $3.2 \mathrm{~mm}$ were bonded to PEKK twenty respectively and classified into six groups (UM, UE, UC, PM, PE and PC). All specimens were stored in distilled water at $37^{\circ} \mathrm{C}$ for 24 hours. SBS of each group was measured at a crosshead speed of $2 \mathrm{~mm} / \mathrm{min}$ in universal testing machine. SBS was compared using one-way ANOVA and a Tukey HSD test $(P=0.05)$. Results: Group UM and group UE showed a significant difference in SBS with group UC $(P<0.05)$. Group PC showed a significant increase in SBS than group UC $(P<0.05)$. Conclusion: It is recommended to apply Visio.link to PEKK for adhering bis-acrylic composite resin, but not for PMMA and PEMA in clinical practice. (J Dent Rehabil Appl Sci 2020;36(1):1-11)
\end{abstract}

Key words: polyetherketoneketone; polymethylmethacrylate; polyethylmethacrylate; bis-acryl composite resin; shear bond strength

\section{Introduction}

Polymers with high esthetics, excellent biocompatibility, and mechanical and chemical properties have attracted considerable attention in the field of dentistry recently. Polyaryletherketone (PAEK), a group of high-performance thermoplastic resins, has been studied because of their excellent mechanical and chemical properties, abrasion resistance, and biocompatibility compared to polymethylmethacrylate (PMMA) or polyethylmethacrylate (PEMA). ${ }^{1-4}$ In addition, PAEK has radiolucency and can be milled using

*Correspondence to: Soo-Yeon Shin

Professor, Department of Prosthodontics, College of Dentistry, Dankook University 119 Dandae-ro, Dongnam-gu, Cheonan, 31116, Republic of Korea

Tel: +82-41-550-0256, Fax: +82-41-550-1975, E-mail: syshin@dankook.ac.kr

Received: July 15, 2019/Last Revision: July 16, 2019/Accepted: January 3, 2020 computer-aided design/computer-aided manufacturing (CAD/CAM). ${ }^{5}$ The physical properties of PAEK depend on the ratio of the ketone-ether groups: the higher the amount of ketone groups compared to ether groups, the higher the strength of PAEK. ${ }^{1,6}$ Polyetheretherketone (PEEK) and polyetherketoneketone (PEKK) are members of the PAEK family and especially PEKK has superior physical properties, such as high flexural and tensile strength and surface hardness than polyetherketone (PEK) or PEEK. ${ }^{7}$ In dentistry, it can be used as temporary fixed restoration, attachment, post, occlusal splint, a temporary

Copyright@ 2020 The Korean Academy of Stomatognathic Function and Occlusion (c) It is identical to Creative Commons Non-Commercial License. 
implant abutment, ${ }^{8-11}$ and removable prosthesis. ${ }^{12}$

According to the manufacturer, PEKK can be used as long-term temporary restoration and shows high fracture strength. ${ }^{1}$ Therefore, it can be applied to cases such as an increase of vertical dimension or full mouth rehabilitation. ${ }^{13}$ Although a temporary restoration made from PMMA can be reinforced with fiber-reinforced resin or a cast metal structure, the fiber-reinforced resin shows lower fracture strength than PEKK, ${ }^{14}$ and adhesion of the cast metal structure to the resin is weakened rapidly after thermocycling. ${ }^{15}$ On the other hand, PEKK can be considered a temporary restoration because of its higher fracture strength than fiber-reinforced resin and high bond strength with PMMA as a polymer. In particular, when an increase of the vertical dimension is required, a temporary fixed restoration made from PEKK or an occlusal splint can be used and it is necessary to adhere to the resin for a progressive increase of the vertical dimension. In addition, when used for a temporary implant abutment, the shape of the abutment can be modified by adhesion with resin for the appropriate emergence profile and soft tissue support. ${ }^{16-18}$ For this reason, this study examined the adhesion between PEKK and resin for a temporary restoration.

Among previous studies on the adhesion between PAEK and other polymers, adhesion between PEEK and composite resin has been studied mainly. High bond strengths can be achieved by appropriate surface treatment and bonding systems. Acid etching using sulfuric acid or piranha acid, ${ }^{19-24}$ plasma treatments, ${ }^{25}$ and air-abrasion ${ }^{19,20,23,26}$ have been reported as surface treatments for PEEK and the airabrasion group was reported to have excellent bond strength. ${ }^{20,23,26}$ For PEKK, the highest bond strength was achieved when silica-coating, universal primer, and resin primer were used. ${ }^{2}$ In addition to the mechanical surface treatment, there is a method of applying a primer. Visio.link (Bredent, Senden, Germany) is a primer containing MMA, and many studies have been reported that high bond strengths were measured with it. ${ }^{19,23-26}$

Therefore, to examine the adhesion of PEKK as a temporary restoration, shear bond strengths (SBS) between PEKK with surface treatment and three types of temporary restorative resin were compared. The null hypotheses were that there is no difference in SBS of the resin depending on the surface treatment method of PEKK and that there is no difference in the SBS according to the type of resin.

\section{Materials and Methods}

In this study, PEKK milling disks (Pekkton Ivory, Cendres+Métaux, Bienne, Switzerland) with a diameter of $98.5 \mathrm{~mm}$ and thickness of $16 \mathrm{~mm}$ were milled to form sixty disks (Fig. 1), $10 \mathrm{~mm}$ in diameter and $5 \mathrm{~mm}$ in thickness. The disks were embedded in a self-polymerizing resin (Ortho-jet, Lang Dental Mfg Co., Wheeling, USA). The PEKK surface was polished stepwise with 400, 600, 800, 100, and 1200 grit $\mathrm{SiC}$ foil (Sandpaper premium grade; R\&B, Daejeon, Korea) using an automated polishing machine (LaboPol-5, Struers, Copenhagen, Denmark) at 400 rpm for 60 seconds under constant water cooling. The specimens were then washed with distilled water for 10 minutes using an ultrasonic cleaner (SD-120H, Mujigae Co., Seoul, Korea) and dried. All specimens were air-abraded (Easyblast, BEGO GmbH, Bremen, Germany) with $110 \mu \mathrm{m}$ alumina particles (Cobra, Renfert GmbH, Hilzinge, Germany) at $0.2 \mathrm{MPa}$ for 10 seconds at a distance of $10 \mathrm{~mm}$ vertically on the surface. After ultrasonic cleaning for 10 minutes in distilled water, Visio.link was applied to thirty PEKK specimens with a microbrush and light cured for 90 seconds using a light emitting diode (LED) light-

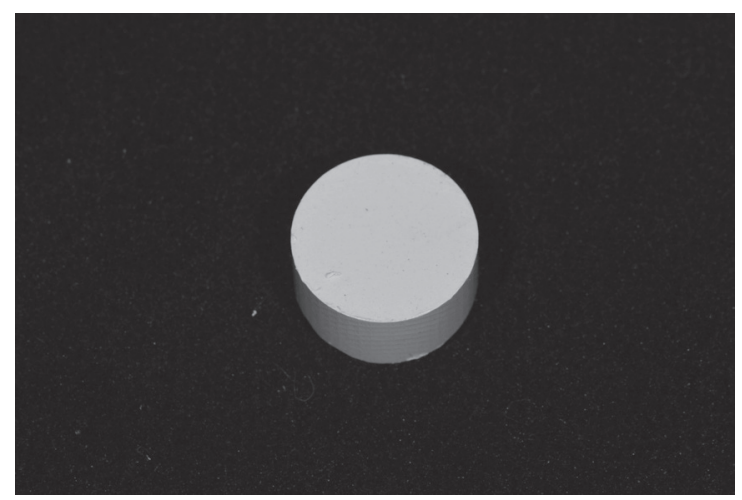

Fig. 1. Polyetherketoneketone. 
curing unit (B\&LiteS, B\&L Biotech, Seoul, Korea) according to the manufacturer's instructions. PEKK specimens were classified into two groups; one without Visio.link (U) and with Visio.link (P). As resins for temporary restorations, polymethylmethacrylate (PMMA) (Jet; Lang Dental manufacturing, Co.), polyethylmethacrylate (PEMA) (Snap; Parkell Inc. Edgewood, USA) and bis-acryl composite resin (Luxatemp Automix Plus; DMG, Hamgurg, Germany) were chosen. Using a styrene square tube, three types of resin for the temporary restorations were fabricated, each of which had a rectangular cross section, 3.2 $\mathrm{mm}$ in length and $5 \mathrm{~mm}$ in height. Resins were attached with the same type of resin by means of an alignment apparatus (Fig. 2). This apparatus consisted of two parallel guides, a tube holder, a silicone pad and an added weight of $750 \mathrm{~g}$. The excess resin was removed with a microbrush and dental probe. According to the application of primer and type of resin, six groups were classified (UM, UE, UC, PM, PE, and PC). All specimens were stored in distilled

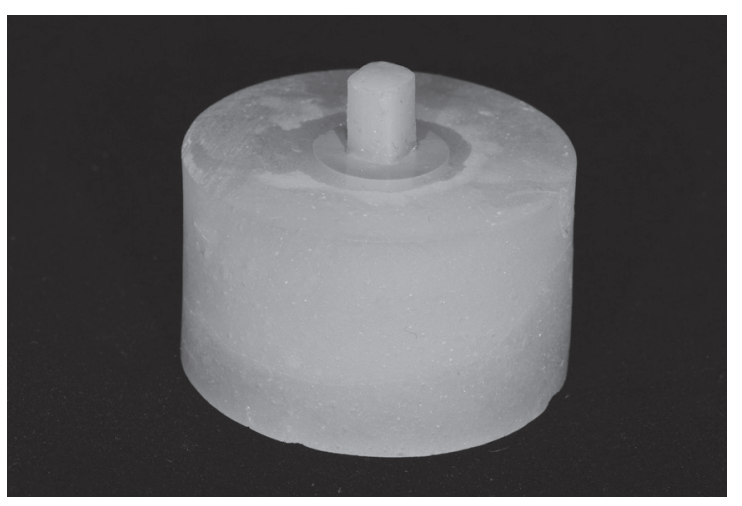

Fig. 2. Specimen. water at $37^{\circ} \mathrm{C}$ for 24 hours. The experiment groups of the specimens are shown in the Table 1 , and 10 specimens were prepared for each group.

SBS was measured using a universal testing machine (OTU-05D; Oriental TM Corp., Siheung, Korea) with $2 \mathrm{~mm} / \mathrm{min}$ crosshead speed and calculated as follows: fracture load/bonding area $\left(\mathrm{N} / \mathrm{mm}^{2}=\right.$ $\mathrm{MPa})$.

A non-contact 3D measuring instrument (NV2000; Nano System Corp., Daejeon, Korea) was used to measure the surface roughness $(\mathrm{Ra})$ of PEKK after air-abrasion and Visio.link application respectively. Specimens were observed with 50, 500 and 1000 $\times$ magnifications by scanning electron microscopy (SEM) (Sigma 500; Carl Zeiss Corp., Oberkochen, Germany).

The fractured specimens were scanned at a 12800 dpi resolution using a digital scanner (EPSON Perfection V500 Photo scanner; Seiko Epson Corp., Nagano, Japan), and $200 \%$ of the samples were transferred to Adobe Photoshop CS5 (Adobe Systems Inc.). The microstructure was observed by SEM. The fracture modes were classified as adhesive failure, cohesive failure in PEKK, and cohesive failure in the resin.

The average of SBS was calculated using the SPSS Statistics for Windows, version 24.0 (SPSS Inc., Chicago, USA) and analyzed statistically. The Komogorov-Smirnov test was used to test the normality of the variables. The significant differences of SBS in the group-to-group were analyzed by one-way ANOVA, and a Tukey HSD was used for a post-test $(P<0.05)$. A Mann-Whitney test was used to analyze the surface roughness $(P<0.05)$.

Table 1. Classification of experiment group

\begin{tabular}{ccll}
\hline Group & Subgroup & N & \multicolumn{1}{c}{ Composition } \\
\hline \multirow{2}{*}{$\mathrm{U}$} & $\mathrm{UM}$ & 10 & PEKK without Visio.link + polymethylmethacrylate \\
& UE & 10 & PEKK without Visio.link + polyethylmethacrylate \\
& UC & 10 & PEKK without Visio.link + bis-acryl compostie resin \\
& PM & 10 & PEKK with Visio.link + polymethylmethacrylate \\
$\mathrm{P}$ & PE & 10 & PEKK with Visio.link + polyethylmethacrylate \\
& PC & 10 & PEKK with Visio.link + bis-acryl compostie resin \\
\hline
\end{tabular}




\section{Results}

The mean and standard deviation of SBS were in the order of PMMA, PEMA, and bis-acryl composite resin with and without Visio.link (Table 2). The $\mathrm{p}$ values of the Kolmogorov-Smirnov test for the normality test were all greater than 0.05 indicating that they follow regularity (Table 3). One-way ANOVA test confirmed the significant differences among the groups $(P=0.003$, Table 4$)$, and the relationship among the groups with a significant difference was confirmed by post-testing with a Tukey HSD test (Table 5). The mean and standard deviation of the SBS of each group and the significance among the groups are shown graphically (Fig. 3).

The surface roughness ( $\mathrm{Ra}$ ) of group $\mathrm{U}$ and

Table 2. Mean and standard deviation of shear bond strengths (MPa)

\begin{tabular}{ccccccc}
\hline Group & UM & UE & UC & PM & PE & PC \\
\hline Mean \pm SD & $19.60 \pm 5.38$ & $16.37 \pm 2.22$ & $7.24 \pm 2.56$ & $15.17 \pm 3.86$ & $14.79 \pm 3.80$ & $12.30 \pm 3.52$ \\
\hline SD: standard deviation. & & &
\end{tabular}

Table 3. Results of Kolmogorov-Smirnov test on shear bond strengths

\begin{tabular}{lccc}
\hline & Statistic & df & Sig. \\
\hline UM & .150 & 10 & .200 \\
UE & .184 & 10 & .200 \\
UC & .165 & 10 & .200 \\
PM & .146 & 10 & .200 \\
PE & .164 & 10 & .200 \\
PC & .118 & 10 & .200 \\
\hline
\end{tabular}

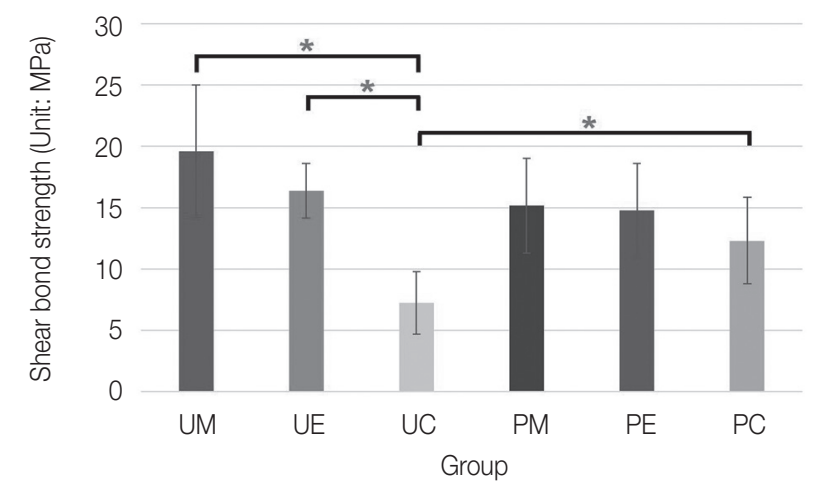

Fig. 3. Bar graph, showing mean shear bond strength of each group tested and result of the Tukey HSD test.

Table 4. Results of one-way ANOVA on shear bond strengths

\begin{tabular}{lccccc}
\hline & Sum of Squares & df & Mean Square & F & Sig. \\
\hline Between groups & .100 & 3 & .033 & 11.299 & $.003^{*}$ \\
Within groups & .024 & 8 & .003 & \\
Total & .124 & 11 & & & \\
\hline
\end{tabular}

$*$ denotes significant difference at level of 0.05 .

Table 5. Results of Tukey HSD test on shear bond strengths

\begin{tabular}{|c|c|c|c|c|c|c|}
\hline & UM & UE & $\mathrm{UC}$ & PM & $\mathrm{PE}$ & PC \\
\hline \multicolumn{7}{|l|}{ UM } \\
\hline UE & .385 & & & & & \\
\hline UC & $<.001^{*}$ & $<.001 *$ & & & & \\
\hline $\mathrm{PM}$ & .097 & .978 & $<.001 *$ & & & \\
\hline $\mathrm{PE}$ & .056 & .929 & $<.001 *$ & 1.000 & & \\
\hline PC & $.001 *$ & .154 & $.039 *$ & .516 & .663 & \\
\hline
\end{tabular}

$*$ denotes significant difference between groups $(P<0.05)$. 
group $\mathrm{P}$ was measured using a non-contact threedimensional measuring instrument (Fig. 4, Table 6). The Mann-Whitney test did not reveal any significant difference in surface roughness $(P>0.05)$. Three-dimensional analysis of the surface roughness of each

Table 6. Mean and standard deviation of surface roughness $(\mathrm{Ra})(\mu \mathrm{m})$

\begin{tabular}{lcc}
\hline & $\begin{array}{c}\text { PEKK without } \\
\text { Visio.link }\end{array}$ & $\begin{array}{c}\text { PEKK with } \\
\text { Visio.link }\end{array}$ \\
\hline Mean \pm SD & $2.62 \pm 0.54$ & $0.93 \pm 0.26$ \\
\hline
\end{tabular}

SD: standard deviation, PEKK: Polyetherketoneketone.

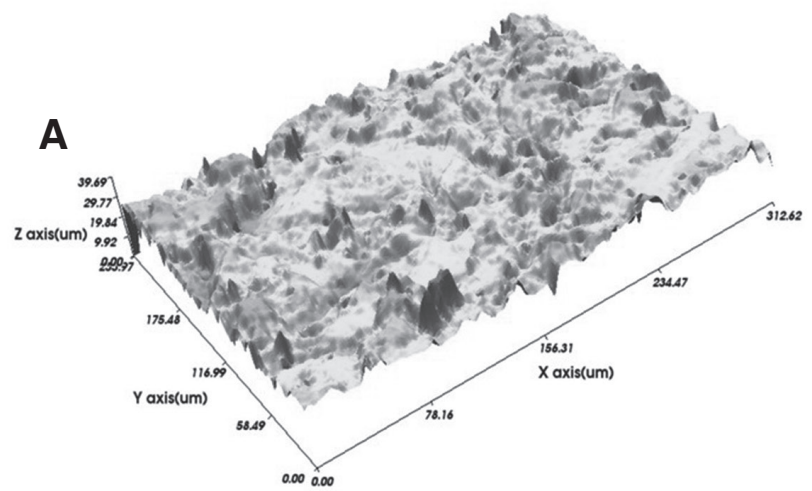

group showed that the group $\mathrm{U}$ had many irregularities due to air-abrasion and showed an uneven surface. On the other hand, group P showed a relatively smooth surface. It is considered that Visio.link filled the surface irregularities caused by the air abrasion.

When the PEKK surface was observed at 50, 500 , and $1000 \times$ magnifications by SEM, the surface treated with air-abrasion showed a rough and uneven surface, which was similar to the results of threedimensional analysis (Fig. 5). When all of the fracture patterns were observed using a digital scanner and SEM, no resin was attached to the surface of PEKK (Fig. 6, 7).

Fig. 4. Non-contact 3D microsurface profile image of the specimens. (A) PEKK without Visio.link, (B) PEKK with Visio.link.

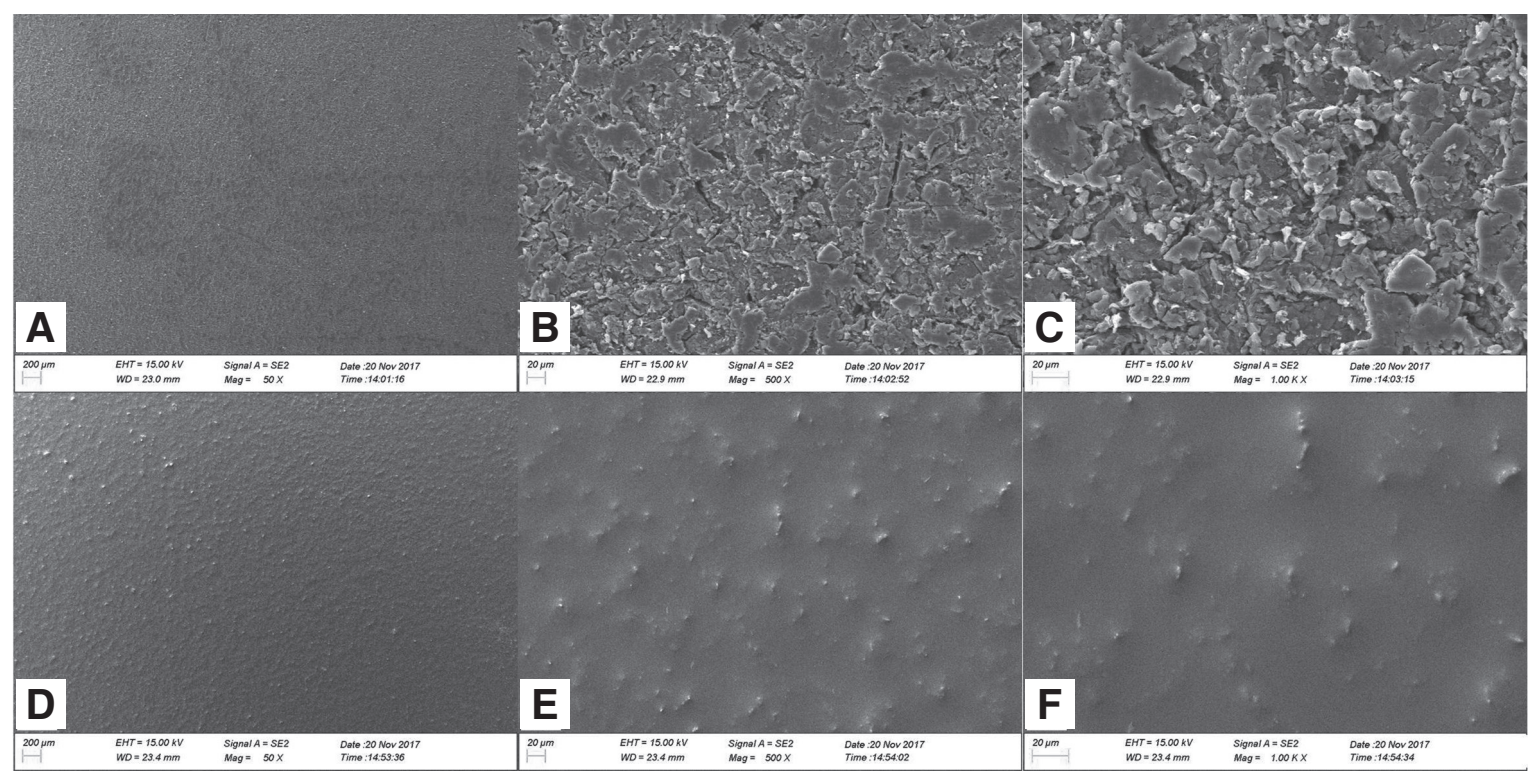

Fig. 5. A SEM image of the specimens. (A) PEKK without Visio.link (50x), (B) PEKK without Visio.link (500x), (C) PEKK without Visio.link (1,000x), (D) PEKK with Visio.link (50x), (E) PEKK with Visio.link (500x), (F) PEKK with Visio.link (1,000x). 


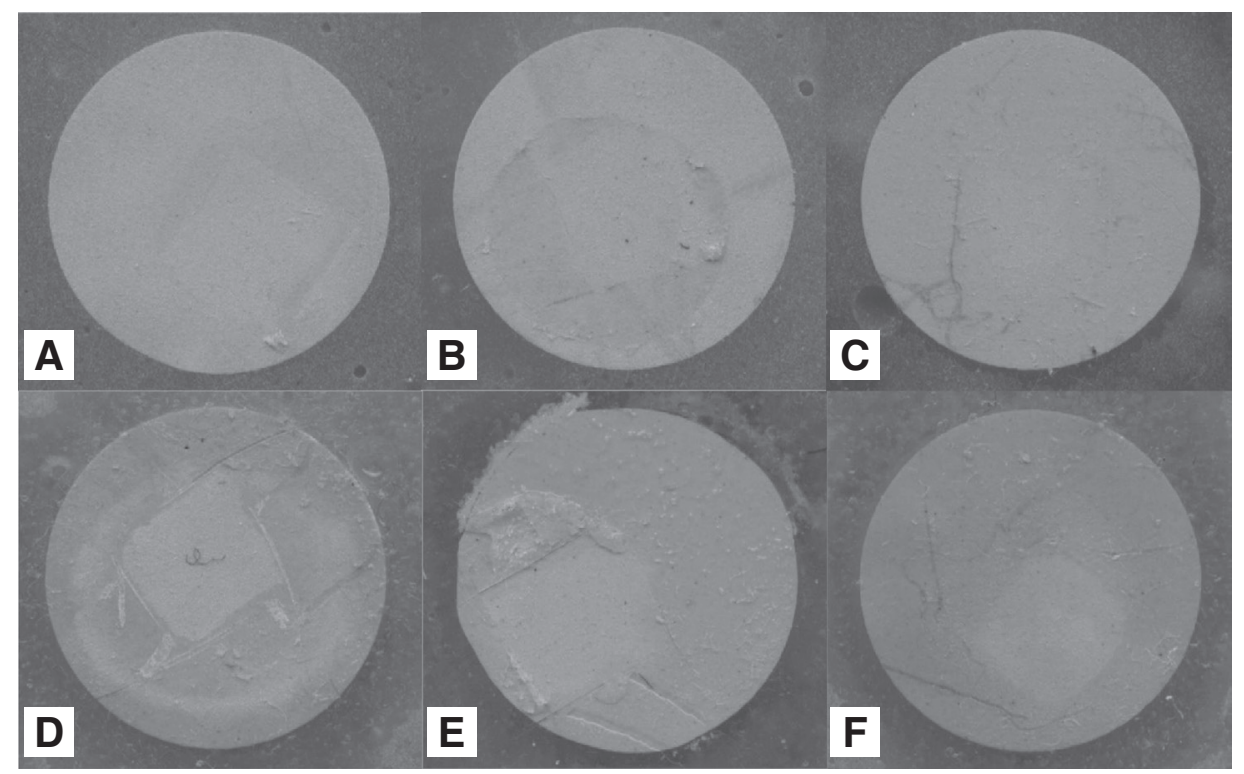

Fig. 6. Digital scanned image of the fractured surface. (A) Group UM, adhesive failure, (B) Group UE, adhesive failure, (C) Group UC, adhesive failure, (D) Group PM, adhesive failure, (E) Group PE, adhesive failure, (F) Group PC, adhesive failure.

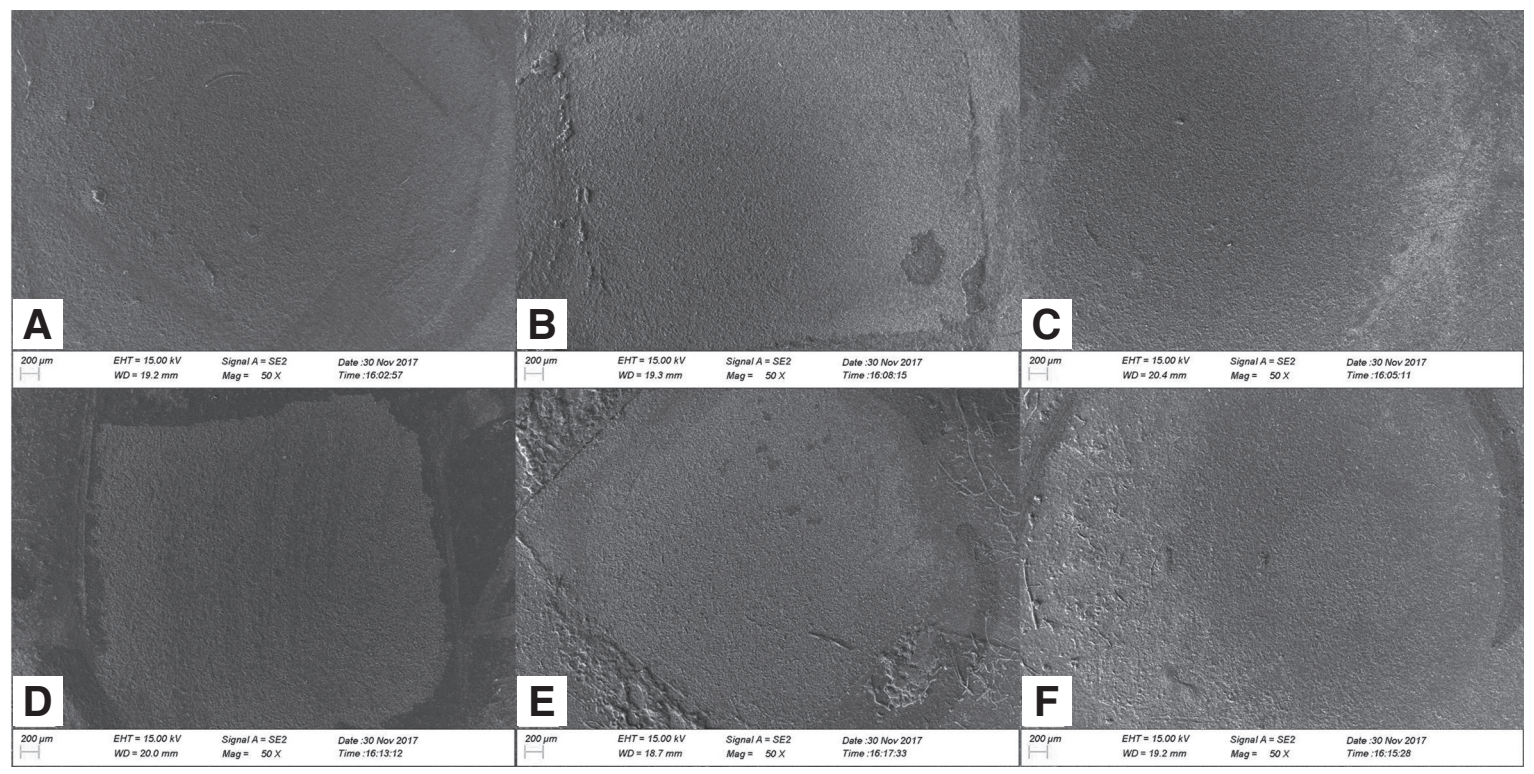

Fig. 7. A SEM image of the fractured surface (50x). (A) Group UM, adhesive failure, (B) Group UE, adhesive failure, (C) Group UC, adhesive failure, (D) Group PM, adhesive failure, (E) Group PE, adhesive failure, (F) Group PC, adhesive failure.

\section{Discussion}

PEKK is a family member of PAEK that is commercially available in the field of dentistry. The material has the best physical, mechanical, and chemical properties among the polymers. To use PEKK with these characteristics as a temporary restoration, such as a temporary fixed restoration or a temporary implant abutment, this study examined whether the surface treatment of PEKK and the type of resins for temporary restoration had an influence on SBS. SBS of group PC was higher than that of group UC $(P<$ 0.05), and SBS of the group UM and group UE were higher than that of group UC $(P<0.05)$. Therefore, 
the first null hypothesis that there was no difference in SBS according to surface treatment method was rejected with a significant difference observed in group PC and group UC. The second null hypothesis that there was no difference in SBS according to the type of resins was also rejected because group UM and group UE showed a significant difference from group UC.

SBS can be different even for the same material depending on the shape and volume of the mechanical analysis. ${ }^{27}$ According to Oliveira et al., when the chisel-shaped shearing blade, $0.5,1.0,2.0$, and $3.0 \mathrm{~mm}$ in width, was used, SBS of the composite resin bonded to the enamel showed a significantly higher SBS with a smaller blade width. ${ }^{28}$ This is consistent with the result of Sinhoreti, who reported that a cleavage effort occurred when a straight chisel was used, indicating that the tension was initially concentrated near the load area, resulting in more complex tension overall. ${ }^{29}$ To reduce the error in SBS measurements, specimens were made to have a rectangular cross section according to the shape of the straight chisel in the experiment. Lee et al. measured the SBS of cylindrical specimens of PEKK with applying Visio.link after air-abrasion using a straight chisel and the bonding strength was 16.33 Mpa. ${ }^{9}$ SBS measured by Lee et al. was higher than that of group PC. SBS measured by Lee et al. seems to show similar bond strength to that of group PC based on the study results that in the case the shear bond strength is measured, the smaller the area of the device in contact with the specimen is, the higher the bond strength is measured.

Mechanical methods for increasing the bond strength to PEEK have been studied and it was reported that piranha acid or plasma treatment has no effect on the bond strength between PEEK and composite resin. ${ }^{20,24,25}$ On the other hand, based on the results using air-abrasion and Visio.link for PEEK, ${ }^{20,26,30}$ the surface treatment of PEKK was carried out with air-abrasion and Visio.link in this experiment. SBS of the PEKK surface treated with $50 \mu \mathrm{m}$ alumina and $110 \mu \mathrm{m}$ silica-coated alumina was similar.' SBS were similar but the bond strength varied depending on the applied pressure. ${ }^{31}$ Lee et al. treated PEKK at $0.5 \mathrm{MPa}$ with $50 \mu \mathrm{m}$ alumina and
$110 \mu \mathrm{m}$ silica-coated alumina at a distance of $5 \mathrm{~mm}$, and then applied Visio.link and measured SBS with the composite resin; the results revealed 17.52 and 16.33 MPa respectively. ${ }^{9}$ These values are higher than SBS of group PC (12.30 MPa). In this experiment, the PEKK was surface treated at a distance of 10 $\mathrm{mm}$ and $0.2 \mathrm{MPa}$.

On the other hand, the bond strength varies according to the use of the primer, which is a chemical surface treatment method for improving the bonding strength. Previous studies reported an increase in bond strength when methylmethacrylate (MMA) was used. ${ }^{25,32}$ Kern and Lehmann reported that when a composite resin was bonded to PEEK using different surface treatments and primers, the tensile bond strength test revealed high values in the group using MMA-containing primers. ${ }^{32}$ Stawarczyk et al. compared the tensile bond strengths of composite resins using various types of primers with PEEK and reported the group using MMA-containing primer to have the highest tensile bond strength. ${ }^{26}$ In another study, the highest fracture strength was obtained when air-abrasion was applied to PEEK and the composite resin was bonded using Visio. link. ${ }^{22}$ Stawarczyk et al. reported that pentaerythritol triacrylate (PETIA) contained in Visio.link plays an important role in PAEK adhesion. ${ }^{33}$ In the present study, there was a significant difference of SBS between group UC and group PC, 7.24 MPa and 12.30 $\mathrm{MPa}$ respectively but no significant difference between group UM and group PM and between group UE and group PE. Stawarczyk et al. reported similar results and explained that the chemical composition of the specimen was important for adhering to the PAEK. In this experiment, Visio.link was effective for the adhesion of bis-acryl composite resin but not for PMMA and PEMA. Visio.link appears to be chemically bonded better to the bis-acryl composite resin than PMMA or PEMA but further studies on the use of other primers that are chemically bonded to PMMA or PEMA will be needed.

Surface roughness analysis was performed to examine the difference in SBS according to application of Visio.link. Lümkemann et al. reported that when air-abrasion was performed at a distance of $10 \mathrm{~mm}$ 
and an angle of $45^{\circ}$ for 10 seconds at $0.2 \mathrm{MPa}$ using $50 \mu \mathrm{m}$ alumina particles on the surface of PEEK, the $\mathrm{Ra}$ value measured by a profilometer was $0.9 \mu \mathrm{m} .^{31}$ Silthampitag et al. reported $0.37 \mu \mathrm{m} .{ }^{34}$ In this experiment, the Ra value of the group $U$ was $2.62 \mu \mathrm{m}$. Because the alumina particle size was $110 \mu \mathrm{m}$ and larger than $50 \mu \mathrm{m}$, the surface was deeper under the same pressure, indicating greater surface roughness. In contrast, the Ra value of the group $\mathrm{P}$ was $0.93 \mu \mathrm{m}$, which was higher than $0.243 \mu \mathrm{m}$ of PEKK without surface treatment reported previously but lower than that of group U. ${ }^{9}$ This is probably because the Visio. link penetrated into the fine irregularities formed by air-abrasion so the overall surface was uniform. There was no statistically significant difference in the $\mathrm{Ra}$ value between group $\mathrm{U}$ and group P. There was significant difference between group UC and group PC only and it is expected that the effect of chemical bonding by Visio.link is greater than the mechanical bonding. In addition, SEM of the group $U$ revealed uneven and coarse appearance compared to that of group $\mathrm{P}$, which is consistent with the results reported. $^{2}$ In group P, small projections were observed on the smooth surface overall and Schmidlin et al. observed similar surfaces. ${ }^{2,35}$ This small protrusions are observed as a component of the primer.

Fuhrmann et al. and Schimidlin et al. reported mainly adhesive failure during the bond strength test between PEEK and composite resin. ${ }^{2,35}$ On the other hand, Lee et al. reported that mixed failure was predominant. ${ }^{9}$ In the present study, the failure mode of the specimens was analyzed using a digital scanner and found to be adhesive failure in all groups. In addition, no resin remained on the PEKK surface by using SEM. There is no cohesive fracture in the fracture pattern so it is considered that the bond strength between PEKK and resin is weaker than the bond strength within PEKK or resin.

The limitation of this study was no artificial aging, such as thermocycling or long-term underwater storage. In the adhesion experiment between PEKK and PMMA, the group subjected to 10,000 times of thermocycling at $5^{\circ} \mathrm{C}$ to $55^{\circ} \mathrm{C}$ showed a lower bond strength than the group not subjected to thermocycling. ${ }^{33}$ In this study, the specimens were stored at $37^{\circ} \mathrm{C}$ for 24 hours in distilled water and the SBS of the specimens after thermocycling is expected to be lower than that before thermocycling. Further research considering the environment in the oral cavity will be needed.

\section{Conclusion}

Within the limitations of this in vitro study, the following conclusions were made.

1. In the PMMA and PEMA groups, there was no significant difference in SBS depending on whether Visio.link was applied or not. On the other hand, in the bis-acryl composite resin group with Visio.link, SBS was significantly higher than that of bis-acryl composite resin group without Visio.link.

2. Values of SBS were in the order of PMMA, PEMA, and bis-acryl composite resin in groups with and without Visio.link but there was no significant difference among three groups with Visio.link.

3. The surface roughness of the PEKK without Visio.link group was higher than that of the PEKK with Visio.link group, but there was no significant difference.

4. Fracture mode was all adhesive fracture in six groups.

Overall, applying Visio.link to PEKK for adhesion of bis-acryl composite resin is expected to provide excellent bonding strength in clinical practice.

\section{ORCID}

Mun Gi Hong https://orcid.org/0000-0002-2557-7362

Soo-Yeon Shin https://orcid.org/0000-0001-6160-7277

\section{References}

1. Kurtz SM, Devine JN. PEEK biomaterials in trauma, orthopedic, and spinal implants. Biomaterials 2007;28:4845-69.

2. Fuhrmann G, Steiner M, Freitag-Wolf S, Kern M. Resin bonding to three types of polyaryletherketones (PAEKs)-durability and influence of surface 
conditioning. Dent Mater 2014;30:357-63.

3. Williams DF, McNamara A, Turner RM. Potential of polyetheretherketone (PEEK) and carbon-fibrereinforced PEEK in medical applications. J Mater Sci Lett 1987;6:188-90.

4. Stawarczyk B, Keul C, Beuer F, Roos M, Schmidlin PR. Tensile bond strength of veneering resins to PEEK: impact of different adhesives. Dent Mater J 2013;32:441-8.

5. Liebermann A, Wimmer T, Schmidlin PR, Scherer H, Löffler P, Roos M, Stawarczyk B. Physicomechanical characterization of polyetheretherketone and current esthetic dental CAD/CAM polymers after aging in different storage media. J Prosthet Dent 2016;115:321-8.

6. Wimmer T, Huffmann AM, Eichberger M, Schmidlin PR, Stawarczyk B. Two-body wear rate of PEEK, CAD/CAM resin composite and PMMA: Effect of specimen geometries, antagonist materials and test set-up configuration. Dent Mater 2016; 32:e127-36.

7. Geringer J, Tatkiewicz W, Rouchouse G. Wear behavior of PAEK, poly (aryl-ether-ketone), under physiological conditions, outlooks for performing these materials in the field of hip prosthesis. Wear 2011;271:2793-803.

8. Bae SY, Park JY, Jeong ID, Kim HY, Kim JH, Kim WC. Three-dimensional analysis of marginal and internal fit of copings fabricated with polyetherketoneketone (PEKK) and zirconia. J Prosthodont Res 2017;61:106-12.

9. Lee KS, Shin JH, Kim JE, Kim JH, Lee WC, Shin SW, Lee JY. Biomechanical evaluation of a tooth restored with high performance polymer PEKK post-core system: a 3D finite element analysis. Biomed Res Int 2017;2017:1373127.

10. Han KH, Lee JY, Shin SW. Implant- and tooth-supported fixed prostheses using a high-performance polymer (Pekkton) framework. Int J Prosthodont 2016;29:451-4.

11. Zoidis P, Papathanasiou I. Modified PEEK resinbonded fixed dental prosthesis as an interim restoration after implant placement. J Prosthet Dent 2016;116:637-41.

12. Tannous F, Steiner M, Shahin R, Kern M. Retentive forces and fatigue resistance of thermoplastic resin clasps. Dent Mater 2012;28:273-8.

13. Burns DR, Beck DA, Nelson SK; Committee on Research in Fixed Prosthodontics of the Academy of Fixed Prosthodontics. A review of selected dental literature on contemporary provisional fixed prosthodontic treatment: report of the Committee on Research in Fixed Prosthodontics of the Academy of Fixed Prosthodontics. J Prosthet Dent 2003; 90:474-97.

14. Vallittu PK. The effect of glass fiber reinforcement on the fracture resistance of a provisional fixed partial denture. J Prosthet Dent 1998;79:125-30.

15. Kim JY, Pfeiffer P, Niedermeier W. Effect of laboratory procedures and thermocycling on the shear bond strength of resin-metal bonding systems. J Prosthet Dent 2003;90:184-9.

16. Tetelman ED, Babbush CA. A new transitional abutment for immediate aesthetics and function. Implant Dent 2008;17:51-8.

17. Wittneben JG, Buser D, Belser UC, Brägger U. Periimplant soft tissue conditioning with provisional restorations in the esthetic zone: the dynamic compression technique. Int J Periodontics Restorative Dent 2013;33:447-55.

18. Harder S, Kern M. Provisional treatment and soft tissue conditioning before and after implantation for single tooth replacement. Implantologie 2010;18:407-15.

19. Hallmann L, Mehl A, Sereno N, Hämmerle C. The improvement of adhesive properties of PEEK through different pre-treatments. Appl Surf Sci 2012;258:7213-8.

20. Keul C, Liebermann A, Schmidlin PR, Roos M, Sener B, Stawarczyk B. Influence of PEEK surface modification on surface properties and bond strength to veneering resin composites. J Adhes Dent 2014;16:383-92.

21. Sproesser O, Schmidlin PR, Uhrenbacher J, Eichberger M, Roos M, Stawarczyk B. Work of adhesion between resin composite cements and PEEK as a function of etching duration with sulfuric acid and its correlation with bond strength values. Int J Adhes Adhes 2014;54:184-90.

22. Sproesser O, Schmidlin PR, Uhrenbacher J, Roos 
M, Gernet W, Stawarczyk B. Effect of sulfuric acid etching of polyetheretherketone on the shear bond strength to resin cements. J Adhes Dent 2014;16: 465-72.

23. Stawarczyk B, Thrun H, Eichberger M, Roos M, Edelhoff D, Schweiger J, Schmidlin PR. Effect of different surface pretreatments and adhesives on the load-bearing capacity of veneered 3-unit PEEK FDPs. J Prosthet Dent 2015;114:666-73.

24. Stawarczyk B, Jordan P, Schmidlin PR, Roos M, Eichberger M, Gernet W, Keul C. PEEK surface treatment effects on tensile bond strength to veneering resins. J Prosthet Dent 2014;112:1278-88.

25. Stawarczyk B, Bähr N, Beuer F, Wimmer T, Eichberger M, Gernet W, Jahn D, Schmidlin PR. Influence of plasma pretreatment on shear bond strength of self-adhesive resin cements to polyetheretherketone. Clin Oral Investig 2014;18:163170.

26. Stawarczyk B, Keul C, Beuer F, Roos M, Schmidlin PR. Tensile bond strength of veneering resins to PEEK: impact of different adhesives. Dent Mater J 2013;32:441-8.

27. Mondragon E, Söderholm KJ. Shear Strength of Dentin and Dentin Bonded Composites. J Adhes Dent 2001;3:227-36.

28. Oliveira ACC, Oshima HMS, Mota EG, Grossi ML. Influence of chisel width on shear bond strength of composite to enamel. Rev odonto Ciênc 2009; 24:19-21.

29. Sinhoreti MA, Consani S, De Goes MF, Sobrinho LC, Knowles JC. Influence of loading types on the shear strength of the dentin-resin interface bonding. J Mater Sci Mater Med 2001;12:39-44.

30. Stawarczyk B, Taufall S, Roos M, Schmidlin PR, Lümkemann N. Bonding of composite resins to PEEK: the influence of adhesive systems and airabrasion parameters. Clin Oral Investig 2018;22: 763-71.

31. Lümkemann N, Strickstrock M, Eichberger M, Zylla IM, Stawarczyk B. Impact of air-abrasion pressure and adhesive systems on bonding parameters for polyetheretherketone dental restorations. Int J Adhes Adhes 2018;80:30-8.

32. Kern M, Lehmann F. Influence of surface condi- tioning on bonding to polyetheretherketon (PEEK). Dent Mater 2012;28:1280-3.

33. Stawarczyk B, Silla M, Roos M, Eichberger M, Lümkemann N. Bonding Behaviour of Polyetherketoneketone to Methylmethacrylate- and Dimethacrylate-based Polymers. J Adhes Dent 2017;19: $331-8$.

34. Silthampitag P, Chaijareenont P, Tattakorn K, Banjongprasert C, Takahashi H, Arksornnukit M. Effect of surface pretreatments on resin composite bonding to PEEK. Dent Mater J 2016;35:668-74.

35. Schmidlin PR, Stawarczyk B, Wieland M, Attin T, Hämmerle CH, Fischer J. Effect of different surface pre-treatments and luting materials on shear bond strength to PEEK. Dent Mater 2010;26:5539. 


\section{Polyetherketoneketone의 표면처리 방법에 따른 임시 보철물 제작용 레진과의 결합 강도 비교 연구}

홍문기 대학원생, 신수연* 교수

단국대학교 치과대학 치과보철학교실

목적: 본 연구의 목적은 polyetherketoneketone (PEKK)의 표면 처리 방식에 따른 세가지 종류의 임시 보철물 제작용 레 진과의 전단결합강도를 비교하는 것이다.

연구 재료 및 방법: 60개의 PEKK 시편을 $110 \mu \mathrm{m}$ 의 산화알루미늄 입자(Cobra, Renfert GmbH, Hilzinge, Germany)로 분사 처리하고 시편에 Visio.link (Bredent, Senden, Germany)를 도포하지 않은 군(U)과 도포한 군(P)으로 30개씩 나누 었다. 이후 한 변이 $3.2 \mathrm{~mm}$ 인 정사각형의 모양으로 polymethylmethacrylate (PMMA), polyethylmethacrylate (PEMA), bis-acryl composite resin을 PEKK에 각각 20개씩 접착하여 총 6개의 군(UM, UE, UC, PM, PE, PC)으로 분류하였다. 완성된 시편은 $37^{\circ} \mathrm{C}$ 의 증류수에 24 시간 보관하였다. 만능재료시험기의 크로스헤드의 속도를 $2 \mathrm{~mm} / \mathrm{min}$ 로 설정하고 전 단결합강도를 측정하였다. 각 군간의 전단결합강도 값의 유의차를 확인하기 위하여 일원배치분산분석(one-way ANO$\mathrm{VA}$ )과 Tukey HSD test를 시행하였다.

결과: $\mathrm{UM}, \mathrm{UE}$ 군은 $\mathrm{UC}$ 군과 유의한 전단결합강도의 차이를 나타내었다 $(P<0.05) . \mathrm{PC}$ 군이 $\mathrm{UC}$ 군보다 높은 전단결합강 도를 나타내었다 $(P<0.05)$.

결론: 임상적으로 PEKK에 PMMA와 PEMA를 접착하는 경우에 Visio.link의 적용이 필요하지 않으나, bis-acryl composite resin을 접착하는 경우에는 Visio.link의 적용이 추천된다.

(구강회복응용과학지 2020;36(1):1-11)

주요어: polyetherketoneketone; polymethylmethacrylate; polyethylmethacrylate; bis-acryl composite resin; 전단결합강도

*교신저자: 신수연

(31116) 충청남도 천안시 동남구 단대로 119 , 단국대학교 치과대학 보철학교실

Tel: 041-550-0256 | Fax: 041-550-1975 | E-mail: syshin@dankook.ac. kr

접수일: 2019년 7월 15일 | 수정일: 2019년 7월 16일 | 채택일: 2020년 1월 3일 